\title{
Analisis Retorika Gibran Rakabuming Pada Panggung Debat Pilwalkot Solo 2020
}

\author{
Syamsul Hidayat $1^{*}$ \\ 1Universitas Negeri Lampung, Indonesia \\ *e-mail: Syamsulhidayat322@gmail.com
}

Article history: Received 07 February 2021; Accepted 14 July 2021; Available online 31 August 2021

\begin{abstract}
Abstrak
Dalam kajian ilmu pengetahuan seni berbicara atau sering disebut dengan retorika seseorang akan lebih mudah menyampaikan maksud dan tujuan dari apa yang dibicarakannya serta terasa enak didengarkannya dan tidak membuat bosan pendengarnya. Retorika merupakan salah satu kunci sukses didalam suatu kampanye atau debat politik karena menggunakan kata-kata yang menarik simpati masyarakat dalam mengkomunikasikan ideologi ataupun program kerja yang mereka tawarkan sehingga nantinya mendapatkan dukungan pada saat pemilihan umum (pemilu). Gibran Rakabuming yang kita ketahui adalah seorang pengusaha muda sukses yang kini melebarkan sayapnya untuk terjun dalam dunia politik yaitu menjadi walikota Surakarta. Dengan berlatar belakang pengusaha yang memiliki kemampuan beretorika yang baik, dapat digunakan untuk mengambil simpatik masyarakat dalam proses pemilihan pilwalkot Surakarta. Penelitian ini berjudul Analisis Retorika Gibran Rakabuming Pada Panggung Debat Pilwalkot Solo 2020. Tujuan dari penelitian ini adalah untuk melihat bagaimana Analisis Retorika Gibran Rakabuming yang digunakan Pada Panggung Deba Pilwalkot Solo 2020 yang ditayangkan langsung oleh metrotv pada 6 November 2020. Berkaitan dengan hal tersebut hasil penelitian menggunakan teori Retorika menurut Aristoteles yaitu ethos, pathos, logos. a)Ethos Gibran Rakabuming mampu menghubungkan kalimat yang terstruktur dan menata ide dalam makna setiap kalimatnya dalam menyampaikan visi misinya, b)Pathos (bukti emosional) dalam penyampaian visi, Gibran Rakabuming mampu membangkitkan rasa emosi, simpatik, dan bangga, olah vokal yang ditunjukkan Gibran sangat lugas dan tegas lantang terdengar jelas, tidak terlalu cepat, dan penggunaan jedanya juga tepat, sehingga sangat meyakinkan untuk mempersuasi masyarakat, c)Logos (bukti logis) Gibran Rakabuming mampu menghubungkan kalimat yang terstruktur dan menata ide dalam makna setiap kalimatnya dalam menyampaikan visi misinya. Walaupun kalimat yang digunakan Gibran Rakabuming cenderung konotatif tetapi struktur kalimat tetap mengandung penalaran yang logis. Metode yang digunakan dalam penelitian ini adalah penelitian kualitatif deskriptif. Objek penelitian ini berfokus dari tayangan yang diselenggarakan metrotv dan diupload chanel Youtube metrotv yang berjudul "Debat Publik Antar Paslon Pilwalkot Surakarta 2020". Dari penelitian yang dilakukan oleh peneliti, peneliti menyimpulkan bahwa Gibran Rakabuming dalam melakukan debat pilwalkot Solo memahami dan menerapkan elemen-elemen retorika (ethos, pathos dan logos). Berdasarkan elemen-elemen retorika tersebut pidato yang dikemukakan oleh Gibran Rakabuming mampu memberi dampak signifikan terhadap kesuksesannya dalam memperoleh kepercayaan publik dan juga meningkatkan presentase kemenangan dalam Pemilihan Wali Kota Surakarta.
\end{abstract}

Kata Kunci:

Retorika; Debat;

Pilwalkot 


\section{Abstract}

In the study of science, the art of speaking or often referred to as rhetoric, a person will more easily convey the intent and purpose of what he is talking about and feel good to hear and not bore the listener. Rhetoric is one of the keys to success in a political campaign or debate because it uses words that attract public sympathy in communicating the ideology or work program they offer so that later they will get support during the general election (election). Gibran Rakabuming, as we know, is a successful young businessman who is now spreading his wings to enter the world of politics, namely to become the mayor of Surakarta. With a background of entrepreneurs who have good rhetorical abilities, it can attract public sympathy in the Surakarta election process. This research is entitled Gibran Rakabuming Rhetoric Analysis at the Solo 2020 Election Debate Stage. The purpose of this study is to see how Gibran Rakabuming's rhetorical analysis was used on the Solo 2020 Election Debate Stage, which was broadcast live on metro tv on 6 November 2020. In this regard, the study's results use the theory of Rhetoric according to Aristotle, namely ethos, pathos, logos. a) Gibran Rakabuming's ethos can connect structured sentences and organize ideas in the meaning of each sentence in conveying his vision and mission, b) Pathos (emotional evidence) in conveying his vision, Gibran Rakabuming can evoke feelings of emotion, sympathy, and pride, though the vocals shown by Gibran very straightforward and firm, the sound is clear, not too fast, and the use of pauses is also appropriate, so it is compelling to persuade the public, c) Logos (logical evidence) Gibran Rakabuming can connect structured sentences and organize ideas in the meaning of each sentence in conveying his vision and mission. Although the sentences used by Gibran Rakabuming tend to be connotative, the sentence structure still contains logical reasoning. The method used in this research is descriptive qualitative research. The object of this research focuses on the broadcasts held by metro tv and uploaded to the metro to Youtube channel entitled "Public Debate Between Surakarta City Election Candidates 2020". From the research conducted by the researcher, the researcher concludes that Gibran Rakabuming, in conducting the Solo mayoral election debate, understood and applied the elements of rhetoric (ethos, pathos, and logos). Based on these rhetorical elements, the speech delivered by Gibran Rakabuming was able to significantly impact his success in gaining public trust and increasing the percentage of victory in the Surakarta Mayor Election.

\section{Keywords:}

Rhetoric; Debate;

Election;

Copyright @ Universitas Pendidikan Ganesha. All rights reserved.

\section{Pendahuluan}

Dalam menjalani kehidupan sehari-hari kita selalu menggunakan bahasa sebagai alat berkomunikasi dengan sesama kita baik melalui bahasa langsung (berbicara) maupun tidak langsung (bahas tulis). Dalam kajian ilmu pengetahuan seni berbicara atau komunikasi ini sering disebut dengan retorika. Orang yang menguasai ilmu retorika atau memiliki retorika yang bagus dalam berkomunikasi maka akan lebih mudah menyampaikan maksud dan tujuan dari apa yang dibicarakannya serta terasa enak didengarkannya dan tidak membuat bosan pendengarnya.

Retorika, bukan hanya ilmu pidato, tetapi meliputi pengetahuan sastra, gramatika, dan logika. Karena dengan rasio tidak cukup untuk meyakinkan orang, untuk meyakinkan orang lain memerlukan teknik-teknik memanipulasi emosi dan menggunakan prasangka untuk menyentuh hati pendengar. Ada berbagai macam maksud yang hendak kita sampaikan seperti meyakinkan, mempengaruhi, mengajak, memerintah dan lain-lain. Keberhasilan kita dalam berkomunikasi 
sangat dipengaruhi oleh beberapa faktor diantaranya adalah logos (meyakinkan dengan logikalogika), patos (kejiwaan atau aspek pisikologi), etos (kepercayaan atau kredibilitas).

Aktivitas retoris, banyak ragamnya. Ada canda, obrolan, basa-basi, tegur-sapa, khutbah, kampanye, diskusi, seminar, konferensi, dan lain-lain. Dengan demikian pada dasarnya retorika itu menjadi bagian yang tidak dapat dipisahkan dengan kehidupan masyarakat. Adapun retorika politik yang dimaksudkan dalam kajian ini adalah retorika yang bertujuan politis, dimana politik itu sendiri adalah siapa memperoleh apa, kapan, dan bagaimana, pembagian nilai-nilai oleh yang berwenang, kekuasaan dan pemegang kekuasaan, pengaruh, tindakan yang diarahkan untuk mempertahankan dan atau memperluas tindakan lainnya(Nimmo, 2005).

Kajian terkait dengan retorika sudah banyak dilakukan, hasil penelitian Aritonang misalnya menyebut bahwa seluruh kandidat gubernur maupun wakil gubernur DKI menggunakan kombinasi gaya retorika politik baik dalam debat publik pertama maupun kedua. Artinya tidak ada kandidat yang menggunakan gaya retorika tunggal. AHY dominan menggunakan gaya retorika nasihat namun mengkombinasikan nasihat serta birokrasi. Sylvi dengan latar belakang birokrasinya menggunakan gaya retorika birokrasi, formal/resmi, nasihat. Basuki Tjahja Purnama alias Ahok menggunakan gaya retorika terbuka, birokrasi, formal sedangkan Djarot mengkombinasikan gaya retorika birokrasi dan nasihat. Anies Baswedan lebih mengedepankan persoanl branding dalam debat dan birokrasi, Sandiaga Uno lebih mengutamakan aspek personal branding dengan latar belakang pengusaha(Aritonang, 2018).

Hasil penelitian Fathurrijal terkait dengan analisis penerapan prinsip retorika di panggung debat antar calon gubernur DKI Jakarta 2017. Menyimpulkan bahwa dari penampilan orasi ketiga cagub-cawagub pada saat debat berlangsung semuanya mampu menerapkan prinsipprinsip retorika politik dengan baik dan sempurna. Aspek- aspek retorika secara umum, seperti etos, pathos dan logos dimiliki oleh semua kandidat, sehingga penampilan ketiga pasang calon gubernur dan wakil gubernur bila dinilai dari penggunaan prinsip-prinsip retorika aristoteles nyaris sempurna dipraktekkannya. Seperti, Inventio (Penemuan), Disposito (penyusunan), Elocutio (Gaya), Memoria (Memori), Pronountatio (Penyampaian) (Fathurrijal, 2019).

Retorika merupakan salah satu kunci dasar yang begitu penting dalam menarik simpati masyarakat untuk mendapatkan dukungan pada saat pemilihan umum (pemilu). Gibran Rakabuming Raka lahir di Surakarta, 1 Oktober 1987 adalah seorang pengusaha Indonesia. Sejak Desember 2010 membuka usaha katering yang diberi nama Chilli Pari. Ia juga merupakan pendiri perusahaan kuliner martabak yang disebut Markobar. Ia adalah putra sulung dari Presiden Joko Widodo. Pada saat ini mencalonkan diri sebagai Walikota Surakarta pada tahun 2020 bersama dengan Teguh Prakoso.

Pasangan gibran-teguh melakukan debat publik antar paslon yang ditayangkan secara langsung di metrotv pada 6 November 2020. Gibran mengawali paparan visi dan misi tentang karakteristik Solo sebagai kota budaya. Solo dinilai kaya warisan budaya yang kental dan tumbuh pesat bergeliat sebagai kota kecil tapi modern. Selanjutnya Gibran-Teguh memaparkan tantangan utama Kota Solo saat ini yakni bangkit dari pandemi Covid-19. Mereka juga berencana melakukan penataan berbagai hal seperti kepadatan penduduk, permukiman, kemacetan, sampah, tata ruang, lingkungan dan sumber daya air.

Gibran-Teguh mengusung visi Mewujudkan Surakarta sebagai Kota Budaya yang Modern, Tangguh, Gesit, Kreatif dan Sejahtera, untuk lima tahun ke depan, yaitu 2020 hingga 2025. Sedangkan misi Gibran-Teguh terdiri tujuh poin penting. Pertama memastikan tidak terjadi peningkatan kasus Covid-19 dan memberi rasa aman kepada seluruh masyarakat. Kedua, masyarakat harus bisa melangsungkan kehidupan ekoniminya. Kelangsungan ekonomi 
masyarakat yang dimaksud tentu saja menyesuaikan dengan tatanan baru kehidupan. Misi ketiga pasangan Gibran-Teguh akan memajukan tata ruang, pariwisata, dan pelestarian budaya untuk kemajuan kota. Keempat, meningkatkan kepemimpinan pemuda di bidang ekonomi, seni budaya dan olah raga. Kelima, mengembangkan semangat gotong royong dan kebhinekaan. Keenam, mewujudkan kemakmuran dan kesejahteraan warga kota. Terakhir, mewujudkan pola kerukunan antar umat beragama yang saling menghormati. Adapun penelitian ini, difokuskan pada analisis retorik Gibran Rakabuming pada debat publik antar paslon pilwalkot surakarta 2020.

\section{Metode}

Metode penelitian pada dasarnya merupakan cara ilmiah untuk mendapatkan data dengan tujuan dan kegunaan tertentu. Berdasarkan hal tersebut terdapat empat kata kunci yang perlu diperhatikan yaitu cara ilmiah, data, tujuan dan kegunaan(Sugiyono, 2013). Metode penelitian adalah suatu cara ilmiah untuk mendapatkan data dengan tujuan dan kegunaan tertentu(Darmadi, 2013).

Metode penelitian ini adalah penelitian kualitatif deskriptif. Penelitian ini biasanya dilakukan oleh para peneliti dibidang sosial dan juga dibidang yang menyoroti masalah terkait dengan perilaku dan peranan manusia. Metode kualitatif dapat digunakan untuk mengungkapkan dan memahami suatu dibalik fenomena. Hal ini dikarenakan metode penelitian kualitatif mampu memberikan rincian yang kompleks tentang fenomena yang sulit di diungkapkan pada metode kuantitatif.

Obyek dikaji melalui penelusuran pustaka, observasi dan pemanfaatan dokumentasi tertulis, arsip atau rekaman pidato dari Gibran Rakabuming. Pengumpulan data dalam penelitian ini dilakukan melalui, kajian Pustaka. Hal ini dilakukan dengan memperbanyak sumber referensi dan bahan pustaka, memungkinkan untuk terkumpul dan teridentifikasinya lebih banyak teori tentang retorika, bahkan pada tataran praktis yakni berpidato. Penelitian ini berfokus pada retorika Gibran Rakabuming pada debat antar paslon pilwalkot Surakarta tahun 2020 yang bertema membangun Surakarta sebagai kota budaya dalam mendukung pembangunan berkelanjutan yang adil dan merata diera digital yang ditayangkan langsung oleh metrotv pada 6 November 2020.

\section{Hasil dan Pembahasan}

\section{Retorika Gibran Rakabuming}

Ada dua aspek yang harus diperhatikan dalam retorika ini yaitu, pertama, pengetahuan mengenai bahasa dan penggunaan bahasa dengan baik. Kedua, pengetahuan mengenai objek tertentu yang akan disampaikan dengan menggunakan bahasa yang baik(Keraf. G, 2007). Dalam pandangan Aristoteles, Retorika merupakan alat persuasi yang tersedia. Maksudnya, seorang pembicara yang tertarik untuk membujuk khalayaknya harus mempertimbangkan tiga bukti retoris, Logika (Logos), Emosi (Pathos), dan Etika / kredibilitas (Ethos)(West, Richard, 2008).

Aristoteles menyebut bahwa suatu orasi atau pidato dapat menjadi efektif, maka orator atau pembicara harus mengikuti tuntunan atau prinsip-prinsip retorika, Aristoteles menyebutnya sebagai kanon, agar orasi atau pidato lebih menggugah, aturan-aturan atau hukum ini harus diterapkan, kanon-kanon ini telah banyak diterapkan di dalam beberapa situasi berbicara(West, Richard, 2008).

\section{Logos}

Logos disebut juga bukti logis. Logos menarik sisi rasional dari manusia, dan bergantung pada kemampuan pendengar dalam memproses informasi. Dalam bukti logis, argument 
memiliki struktur dalam pembentukannya. Struktur argument terbaik menjadi dua jenis, yaitu inductive argument dan deductive argument.

Dalam logos, terdapat pula reasoning yakni penggambaran atau penarikan kesimpulan dari bukti-bukti yang dipaparkan. Menurut Lucas, reasoning menjadi penting karena dalam keseharian manusia, kita dibombardir dengan pesan yang persuasive baik dari televisi hingga kampanye politik.

Dalam proses komunikasi melibatkan sebuah penjelasan yang terstruktur dari penalaran atau reasoning. Lebih lagi, reasoning dan critical thinking mendasari kehidupan manusia seharihari. Mereka melibatkan segala kemampuan untuk menghubungkan dan menata ide. Kemampuan tersebut dibagi menjadi tiga, analysis (analisis), inference (penarikan kesimpulan) dan evaluation (evaluasi)(Lewis, 1994).

Dalam keterkaitan dengan retorika Gibran Rakabuming pada debat antar paslon pilwalkot Surakarta 2020 hampir semua kata-kata yang disampaikan mampu mengungkapkan penalaran yang logis untuk menyampaikan visi dan misinya. Gibran Rakabuming mampu menghubungkan kalimat yang terstruktur dan menata ide dalam makna setiap kalimatnya dalam menyampaikan visi misinya. Walaupun kalimat yang digunakan Gibran Rakabuming cenderung konotatif tetapi struktur kalimat tetap mengandung penalaran yang logis.

"Sebelum saya ke inti materi visi misi dan program harus kita ketahui bahwa Solo saat ini memiliki dua tantangan besar yang harus kita hadapi. Tantangan pertama adalah masalah covid dampaknya hanya bukan dikesehatan saja tapi juga ke ekonomi. Tantangan yang kedua adalah keberlangsungan kota Solo sebagai kota budaya yang modern seperti kota-kota lain, kota solo ini juga menghadapi kemacetan, kepadatan penduduk dan masalah sampah. Dengan memahami konteks permasalahan tadi saya dan pak teguh menawarkan visi mewujudkan Surakarta sebagai kota budaya yang modern, tangguh, gesit, kreatif dan sejahtera".

\section{Etos}

Yang kedua merupakan ethos, atau yang dikenal sebagai sumber kredibilitas. Kredibilitas pada faktanya didapat karena individu tersebut mendapatkan hak untuk berbicara. Kompetensi, kelayakan, dinamis, dan landasan yang sama. Tidak lupa keahlian personal, karisma, personalitas. Menurut Lucas, selain kompetensi, karakter atau bagaimana audience mengacu pada ketulusan pembicara, dapat dipercaya dan perhatiannya pada kebaikan audience adalah salah satu faktor kredibilitas. Seseorang tidak terpersuasi hanya karena bukti yang dipaparkan, tapi oleh siapa bukti tersebut dipaparkan (Pearson, Judy C.. Paul E. Nelson, Scott Titsworth, 2003).

Retorika Gibran Rakabuming pada debat antar paslon Surakarta memiliki kemampuan yang intelektual sebagai komunikator yaitu dilihat dari tutur bahasanya yang high contex, dan terstruktur. Setiap kata atau kalimat Gibran mengandung makna konotatif. Hal ini menunjukkan kredibilitasnya sebagai pembicara (komunikator) pada saat beliau mengatakan dengan tegas dan lugas menyampaikan visi misinya.

\section{Pathos}

Pathos atau bukti emosional. Mempersuasi orang secara emosional lebih cepat diterima dari pada secara logika. Emosi yang paling sering digunakan adalah rasa takut. Pathos merupakan bukti yang menarik emosi. Untuk menggunakan pathos, seorang pembicara harus memahami hal-hal berikut: 1 . keadaan pikiran / state of mind dari audience 2 . arah tentangan emosi mereka 3. sebab mereka merasalan hal tersebut. Persuader menganalisa keadaan emosi dari pendengarnya, lalu merancang pendekatan yang artistic untuk diarahkan kepada emosi 
tersebut. Para pelajar modern menyebut pathos sebagai daya tarik emosional. Daya tarik emosional digunakan untuk membuat pendengar merasa bersalah, sedih, marah, takut, bahagia, bangga, simpatik, menghormati atau suka.

Dalam penyampaian visi, Gibran Rakabuming mampu membangkitkan rasa emosi, simpatik, dan bangga, olah vokal yang ditunjukkan Gibran sangat lugas dan tegas lantang terdengar jelas, tidak terlalu cepat, dan penggunaan jedanya juga tepat, sehingga sangat meyakinkan untuk mempersuasi masyarakat. 'Visi ini adalah gerak bersama antara pemerintahan dan segenap warganya beralaskan gotong royong sebagai modal sosial budaya'.

Pada pembahasan ini akan membahas narasi Gibran Rakabuming pada debat publik perdana antar paslon pilwalkot Surakarta 2020 yang ditayangkan langsung oleh metrotv pada 6 November 2020 yang melibatkan akademisi, pengamat dan tokoh masyarakat. Di antaranya, Dekan FISIP Universitas Sebelas Maret (UNS) Prof. Dr. Ismi Dwi Astuti, MSi, pengamat komunikasi politik yang juga Kepala Program Studi Ilmu Komunikasi FISIP UNS Sri Hastjarjo, PhD, aktivis Ahmad Rifai, aktivis disabilitas Pamikatsih dan Gunawan Setiawan seorang pengusaha batik asal Kampung Batik Kauman.

"Baik, terima kasih. Assalamu'alaikum Warohmatullah Wabarokatuh, hadirin yang saya hormati sebelum saya ke inti materi visi misi dan program harus kita ketahui bahwa Solo saat ini memiliki dua tantangan besar yang harus kita hadapi. Tantangan pertama adalah masalah covid dampaknya hanya bukan dikesehatan saja tapi juga ke ekonomi. Tantangan yang kedua adalah keberlangsungan kota Solo sebagai kota budaya yang modern seperti kota-kota lain, kota solo ini juga menghadapi kemacetan, kepadatan penduduk dan masalah sampah. Dengan memahami konteks permasalahan tadi saya dan pak teguh menawarkan visi mewujudkan kota Solo sebagai kota budaya yang modern, tangguh, gesit, kreatif dan sejahtera". Visi ini adalah gerak bersama antara pemerintahan dan segenap warganya beralaskan gotong royong sebagai modal sosial budaya'. Kembali lagi masalah covid, Solo dan Indonesia ini berdampak semua tatanan global juga terseret krisis, oleh karena itu perlu percepatan pemulihan kesehatan dan percepatan pemulihan ekonomi. Untuk masalah kesehatan, kita harus konsisten menerapkan tiga M adaptasi kebiasaan baru lalu kita akan meningkatkan pelayanan dan kualitas puskesmas dan RSUD di kota Solo yang ketiga kita harus tingkatkan semangat gotong royong dan solidaritas warga melalui program joko tonggo dan kampung siaga covid. Untuk masalah ekonomi saya dan pak Teguh akan memfasilitasi restrukturisasi untuk UMKM dan memperbanyak program padat karya terutama untuk yang terserang PHK. Lalu yang ketiga kita juga memberikan kelonggaran pembayaran pajak daerah dan retribusi untuk UMKM lalu untuk membuka pelung, saya juga akan membuka peluang kreatif $H A B$. Ini juga saya berharap anak muda di kota Solo memiliki daya saing dan UMKM di kota Solo bisa naik kelas melalui tekhnologi digital, saya optimis Solo bisa bangkit dari Covid jika warganya sehat ekonomi kuat dan kita akan memperketat tempat-tempat yang produktif seperti kantor dan pasar. Sekali lagi saya dan pak teguh optimis Solo bisa bangkit dari covid. Terima kasih.

Dalam berpidato memang tidak pernah lepas dari salam pembuka (sapaan), secara sistematis setelah adanya salam pembuka, maka akan dilanjut dengan pembahasan awal atau kita kenal dengan pendahuluan. Berikut ini kutipan data tentang pendahuluan pidato saat Gibran Rakabuming menyampaikan visinya dalam debat pilwalkot Surakarta 2020:

"Baik, terima kasih. Assalamu'alaikum Warohmatullah Wabarokatuh, hadirin yang saya hormati sebelum saya ke inti materi visi misi dan program harus kita ketahui bahwa Solo saat ini memiliki dua tantangan besar yang harus kita hadapi. Tantangan pertama adalah masalah covid dampaknya hanya bukan dikesehatan saja tapi juga ke ekonomi. Tantangan yang kedua adalah keberlangsungan kota Solo sebagai kota budaya yang modern seperti kota-kota lain, kota solo ini juga menghadapi kemacetan, kepadatan penduduk dan masalah sampah." 
Pada awal kalimat Gibran Rakabuming mengucapkan terima kasih dan mengucapkan salam lalu menjelaskan tentang masalah yang dihadapi kota Solo yakni masalah covid dan keberlangsungan kota Solo sebagai kota budaya yang modern. Gibran menggunakan kalimat konotatif yang memiliki makna mendalam. Kalimat diawal menggambarkan bahwa situasi kota Solo yang sedang mengalami permasalahan ekonomi yang merosot disebabkan oleh pandemi covid dan keberlangsungan kota Solo sebagai kota budaya yang modern. Hal ini bertujuan untuk mempersuasi masyarakat dengan mengunakan teknik pathos dengan mengambil sisi emosi dan simpatik dari masyarakat. Lalu dari tutur kalimat yang disampaikan Gibran Rakabuming mengenai penjelasan dampak covid terhadap perekonomian kota Solo adalah merupakan teknik logos retorika yaitu menyatakan sesuatu yang sesuai dengan logika serta terstruktur.

Data tersebut merupakan bentuk penyampain visi misi dan program kerja Gibran Rakabuming kepada warganya yang hadir pada debat terkait program kerjanya, dari situlah kepiawaian Gibran Rakabuming untuk membangun suasana yang hangat. Setelah itu pada data di atas disebut dengan pembukaan pada pidato. Sebelum ke bagian inti, Gibran Rakabuming memberi gambaran situasi maupun bercerita akan pengalaman sebelumnya dalam membuat program kerja yang efisien dan membangun suasana debat lebih hangat. Dalam suasana debat seseorang tidak hanya harus pandai berbicara melainkan pandai pula dalam mengatur suasana, sehingga dalam menyampaikan gagasannya, pendukung tidak sepenuhnya jenuh melainkan semakin antusias untuk mengetahui akan gagasan apa yang selanjutnya akan disampaikan, dengan begitu kesan pertama dalam pembangunan materi ada pada sapaan dan pendahuluan sehingga dengan begitu Gibran Rakabuming mampu mempengaruhi pendukungnya.

\section{Bagian Utama (isi)}

Pada bagian ini menjelaskan tentang isi yang dikemukakan Gibran Rakabuming dalam debat publik yang menyampaikan visinya yang begitu lantang. Berikut kutipan pernyataan Gibran Rakabuming dalam debat publik pemilihan walikota Surakarta 2020.

"Dengan memahami konteks permasalahan tadi saya dan pak teguh menawarkan visi mewujudkan kota Solo sebagai kota budaya yang modern, tangguh, gesit, kreatif dan sejahtera."

Pada kalimat ini Gibran Rakabuming memberikan angin segar atau solusi melalui visinya kepada masyarakat untuk kemajuan kota Solo yang sedang mengalami ketidak setabilan ekonomi yang disebabkan oleh pandemi covid dan masalah budaya di kota Solo. Sistematika selanjutnya yakni tentang pembuktian, hal ini dilakukan untuk menanamkan pengaruh kepada masyarakat, sehingga Gibran Rakabuming mampu membawa konsep-konsepnya dengan baik dan berdasarkan data maupun fakta sesuai yang dipaparkan dalam debat publik.

\section{Bagian Penutup}

Penutup pada umunya terdiri dari rangkuman, tindakan kongkret yang harus dijalankan, tuntutan dan harapan. Di dalam Dispositio atau sistematika penyusunan dalam berpidato terdapat bagian isi yang merupakan pernyatan, argumen dan penutup. Berikut ini kutipan penutup terkait debat publik dalam pemilihan walikota Surakarta 2020.

"Kembali lagi masalah covid, Solo dan Indonesia ini berdampak semua tatanan global juga terseret krisis, oleh karena itu perlu percepatan pemulihan kesehatan dan percepatan pemulihan ekonomi. Untuk masalah kesehatan, kita harus konsisten menerapkan tiga M adaptasi kebiasaan baru lalu kita akan meningkatkan pelayanan dan kualitas puskesmas dan RSUD di kota Solo yang ketiga kita harus tingkatkan semangat gotong royong dan solidaritas warga melalui program joko tonggo dan kampung siaga covid. Untuk masalah ekonomi saya dan pak Teguh akan memfasilitasi restrukturisasi untuk UMKM dan memperbanyak program padat karya terutama untuk yang terserang PHK. Lalu yang ketiga kita juga memberikan kelonggaran pembayaran pajak daerah 
dan retribusi untuk UMKM lalu untuk membuka pelung, saya juga akan membuka peluang kreatif HAB. Ini juga saya berharap anak muda di kota Solo memiliki daya saing dan UMKM di kota Solo bisa naik kelas melalui tekhnologi digital, saya optimis Solo bisa bangkit dari Covid jika warganya sehat ekonomi kuat dan kita akan memperketat tempat-tempat yang produktif seperti kantor dan pasar. Sekali lagi saya dan pak teguh optimis Solo bisa bangkit dari covid. Terima kasih".

Pada kalimat ini Gibran Rakabuming membuat citra sebagai pemimpin publik yang dapat dipercaya dan meyakinkan masyarakat untuk memilihnya. Pada kalimat ini Gibran mengungkapkan kredibilitas dirinya yang sanggup memimpin kota Solo selama lima tahun kedepan. Gibran Rakabuming menggunakan teknik retorika ethos, pathos, logos untuk mempersuasi masyarakat agar dapat memilihnya dalam pemilihan pilwalkot Solo 2020.

\section{Elocutio (Gaya)}

Pada pemilihan kata-kata dan penggunaan bahasa yang tepat untuk mengemas pesannya. Penggunaan bahasa dalam retorika umum digunakan oleh semua elemen yang berkecimpung dalam dunia politik. Penggunaan bahasa dilakukan dengan cara pemilihan kata secara khusus sehingga mampu menarik dan mempengaruhi pihak lain agar percaya, dengan ide-ide atau gagasan politik yang disampaikan penutur. Gibran Rakabuming merupakan satu di antara tokoh pemuda, hal tersebut dilihat dari pengalaman beliau dalam kepiawaiannya berbicara dan kemampuannya dalam menyampaikan gagasan.

\section{Asindeton}

Suatu gaya yang berupa acuan, bersifat padat dan mampat yang mana beberapa kata, frasa, atau klausa yang sederajat tidak dihubungkan dengan kata sambung. Bentuk-bentuk itu biasanya dipisahkan saja dengan koma, seperti ucapan terkenal dari Julius Caesar: Vini, vidi, vici. Berdasarkan data di atas terdapat gaya bahsa asindeton yang memiliki kepadatan dari beberapa kata, frasa, atau klausa yang sederajat dan tidak dihubungkan dengan kata sambung. Biasanya hanya dipisahkan dengan tanda koma. Seperti kata joko tonggo sebagai kiasan dari Gibran Rakabuming.

\section{Eufemismus}

Kata eufemisme adalah semacam acuan berupa ungkapanungkapan yang tidak menyinggung perasaan orang, atau ungkapan-ungkapan yang halus untuk menggantikan acuanacuan yang mungkin dirasa menghina, menyinggung perasaan atau mensugestikan sesuatu yang tidak menyenangkan. Gaya bahasa eufemismus merupakan gaya bahasa yang memiliki tujuan yang baik dengan ungkapan yang tidak menyinggung perasaan orang.

\section{Simpulan dan Saran}

Yang didapat pada penelitian ini adalah bahwa Gibran Rakabuming dalam debat antar paslon pilwalkot Surakarta tahun 2020, memahami dan menerapkan elemen-elemen penting dalam membangun keberhasilan sebuah retorika dan berhasil. Dari penelitian yang didapat, Gibran Rakabuming berhasil menerapkan dan mengaplikasikan teori ilmu retorika yang berpendapat bahwa ada tiga jenis pendekatan untuk keberhasilan dalam mempersuasi audiens yakni logos, pathos, dan ethos. Gibran dalam menyampaikan pesannya, ekspresi wajahnya terlihat datar namun jawabannya pasti dan tidak menimbulkan kebingungan pada pendengarnya serta memiliki gaya tersendiri yaitu lugas, tegas, dan berwibawa sehingga membuat audiens semakin bersemangat dalam mendengarkan penajaman visi dan misinya. Ada beberapa catatan yang ingin penulis sampaikan, tentunya saran-saran ini disampaikan bertujuan untuk kebaikan dan kualitas penulisan dimasa yang akan datang. Perlu dikembangkan lagi pada referensi pustaka mengenai retorika ataupun sumber teori yang berkaitan dengan Public Speaking (retorika). Dan tentunya sebagai akademisi jangan pernah berhenti untuk menggali pengetahuan dan mengembangkan teori-teori komunikasi, khususnya teori retorika. 


\section{Daftar Pustaka}

Aritonang, A. I. (2018). Gaya Retorika Pasangan Kandidat Cagub \& Cawagub DKI Dalam Debat Politik. Komunikatif, 7 , 154-187. http://journal.wima.ac.id/index.php/KOMUNIKATIF/article/view/1831

Darmadi, H. (2013). Metode Penelitian Pendidikan dan Sosial. Alfabeta.

Fathurrijal. (2019). Analisis Penerapan Prinsip Retorika di Panggung Debat Antar Calon Gubernur DKI Jakarta 2017. Al-I'lam; Jurnal Komunikasi Dan Penyiaran Islam, 3, 29-46. https://www.researchgate.net/publication/337687690_Analisis_Penerapan_Prinsip_Retor ika_di_Panggung_Debat_Antar_Calon_Gubernur_DKI_Jakarta_2017

Keraf. G. (2007). Argumentasi dan Narasi. PT Gramedia Pustaka Utama.

Lewis, G. dan C. S. (1994). Intercultural Communication Competence) (Edisi 2).

Nimmo, D. (2005). Komunikasi Politik. Rosdakarya.

Pearson, Judy C.. Paul E. Nelson, Scott Titsworth, L. H. (2003). Human Communication. The McGraw-Hill Companies.

Sugiyono. (2013). Metodelogi Penelitian Kuantitatif, Kualitatif Dan R\&D. Alfabeta.

West, Richard, L. H. T. (2008). Pengantar Teori Komunikasi Analisis dan Aplikasi (Edisi 3). Salemba Humanika. 